\title{
PEMANFAATAN LIMBAH KERTAS SEBAGAI BAHAN BAKU BIOETHANOL OLEH AKTIVITAS ENZIMATIS FUNGI DAN RAGI
}

\author{
Amanda Frisilla Oktafrianti \\ Jurusan Teknik Lingkungan, Fakultas Arsitektur Lanskap dan Teknologi Lingkungan, \\ Universitas Trisakti, Jakarta, Indonesia
}

Email korespondensi: amanda08215004@std.trisakti.ac.id

\begin{abstract}
ABSTRAK
Kertas merupakan unsur terbesar dari limbah padat yang mengandung serat lignosellulosa. Biomassa lignoseslulosa termasuk dalam sumber daya yang dapat diperbarui sebagai bahan baku bioethanol. Limbah kertas mengandung lignoselulosa yang dapat dirubah menjadi pati lalu kemudian dipecah menjadi glukosa yang nantinya akan menghasilkan bioethanol dengan memanfaatkan aktifitas enzimatis fungi. Dalam pembuatan bioethanol diawali dengan proses delignifikasi untuk mendapatkan gula yang siap untuk di fermentasi dan dilanjutkan dengan proses hidrolisis yang dapat dilakukan dengan menggunakan katalisator kimia, dan katalisator biologi. Karya ilmiah ini bertujuan untuk memberikan informasi mengenai teknologi pemanfaatan limbah kertas menjadi bioethanol dengan memanfaatkan aktivitas enzim fungi dan ragi. Dengan demikian, dari penelitian sebelumnya Persentase makasimum bioethanol yang dihasilkan sebesar $6,849 \%$ v/v (kultur murni) dan 6,031\% v/v (kultur yang diisolasi).
\end{abstract}

Kata Kunci: Kertas, Bioethanol, Fungi, Ragi

\section{PENDAHULUAN}

Kertas merupakan bahan tipis dan juga rata yang dihasilkan dengan kompresi serat yang berasal dari pulp. Serat yang digunakan dalam pembuatan kertas merupakan serat alami yang mengandung selulosa dan hemiselulosa. Dalam pembuatan kertas bahan yang sering digunakan merupakan gabungan antar serat panjang dan serat pendek untuk menghasilkan kertas yang kuat dan halus. Kertas sudah menjadi salah satu kebutuhan penting dalam kegiatan sehari-hari, sehingga pemakaian kertas setiap harinya sangat besar. Kebutuhan kertas yang sangat besar dapat mendorong produksi industri kertas, selain itu kebutuhan kertas yang sangat besar dapat menimbulkan masalah-masalah lain diantaranya adalah masalah lingkungan yaitu penebangan pohon di hutan, pencemaran air dan udara dan juga sampah kertas yang menumpuk.

Kertas merupakan salah satu unsur terbesar dari limbah padat yang menjadi masalah utama untuk di buang di negara-negara maju dan berkembang dikarnakan kapasitas dan lokasi TPA yang semakin berkurang (Byadgi dan Kalburgi, 2016). Limbah kertas mengandung serat lignosellulosa, serat ini dapat diubah menjadi gula sederhana melalui proses hidrolisis. Kemudian gula yang terbentuk diubah menjadi etanol melalui proses fermentasi (Ramayanti dan Ketty, 2017). Menurut Anwar (2012) bahan lignoselulosa adalah sumber daya terbarukan yang melimpah untuk produksi biofuel dari fermentasi organisme Saccharomyces cereviceae. Maksud dari karya ilmiah ini adalah untuk mengolah limbah kertas menjadi ethanol dengan memanfaatkan aktivitas fungi Aspergillus fumigatus dan ragi Saccharomyces cereviceae. Tujuan dari karya ilmiah ini adalah untuk memberikan informasi mengenai teknologi pemanfaatan limbah kertas HVS menjadi 
bioethanol dengan memanfaatkan aktivitas enzim fungi Aspergillus fumigatus dan ragi Saccharomyces cereviceae.

\section{TINJAUAN PUSTAKA}

Pada umumnya sampah kertas dibuang begitu saja dan tidak dimanfaatkan. Penumpukan sampah kertas tentu saja memberikan dampak buruk bagi lingukungan, baik dari segi keindahan maupun kesehatan. Sampah kertas pada saat sekarang ini sebagian besar masih dipandang sebagai limbah lingkungan yang tidak berguna dan banyak menumpuk. Hal seperti ini berpotensi buruk bagi lingkungan sekitar seperti kebersihan yang tidak terjaga diakibatkan sampah kertas yang dibuang dengan asal. Dan juga pemanasan global yang bisa terus meningkat diakibatkan sampah kertas yang di bakar (Dahlan, 2011).

Energi merupakan salah satu permasalahan utama pada saat ini. Namun dibalik ancaman serius di atas ada peluang bagi energi - energi alternatif, khususnya energi yang dapat diperbaharui (renewable energy) untuk dimanfaatkan secara optimal. Salah satu energi terbarukan yang mempunyai potensi besar di Indonesia adalah biomassa. Biomassa dapat digunakan sebagai bahan baku untuk pembuatan bioetanol yang dapat digunakan sebagai bahan bakar alternatif untuk bensin (Ramayanti dan Ketty, 2017).

Sumber daya energi fosil semakin berkurang dari hari ke hari, orang mulai mencari sumber-sumber terbarukan untuk memenuhi kebutuhan energi mereka. Bahan limbah lignoselulosa adalah sumber yang menjanjikan untuk produksi bioethanol (Kurien dkk., 2010).

Bioetanol telah dianggap sebagai bahan bakar cair yang menjanjikan. Meskipun kepadatan energi etanol adalah sekitar dua pertiga dari bensin, jumlah campuran etanol oktan tinggi (106-110 vs 91-96 untuk bensin) dan 34,7\% oksigen (nol dalam bensin) memberikan beberapa manfaat ketika dicampur dengan bensin. Selain angka oktan tinggi, etanol memberikan keuntungan entalpi penguapan yang lebih tinggi, kecepatan laminar yang lebih tinggi, dan panas penguapan yang lebih tinggi, yang bersama-sama membuat campuran etanol bahan bakar transportasi yang sangat menjanjikan (Zabed dkk., 2017).

Menurut Kumar dan Vijay (2018) Etanol dapat diproduksi dari fermentasi gula yang diperoleh dari berbagai sumber biomassa. Sumber daya ini dapat diklasifikasikan secara luas menjadi tiga jenis: tanaman gula (tebu, sorgum manis, dll.), Tanaman pati (jagung, gandum, dll.), Dan biomassa selulosa (brangkasan jagung, switchgrass, dll.). Etanol dari gula dan bahan baku pati biasanya disebut sebagai biofuel generasi pertama dan etanol dari biomassa selulosa dikenal sebagai etanol generasi kedua. Selain selulosa, bahan baku selulosa terutama terdiri dari hemiselulosa dan lignin, dan oleh karena itu, sering disebut sebagai biomassa lignoseluler. Biomassa selulosa, seperti residu pertanian, limbah kehutanan, dan tanaman energi, memberikan keuntungan dengan biaya rendah, ketersediaan berlimpah, dan yang paling penting, adalah sumber non-pangan untuk produksi biofuel.

Menutur Varotkar (2016) biomassa lignoselulosa seperti bahan kertas adalah bagian dari tanaman berdaun atau kayu yang pada dasarnya terdiri dari senyawa selulosa, hemiselulosa dan lignin. Selulosa, komponen utama dinding sel tanaman, terdiri dari rantai panjang glukosa yang dihubungkan oleh $(\beta-1,4)$ - ikatan glikosidik. Rantai ini disusun dalam bundel yang terkait dengan ikatan hidrogen yang membentuk komponen utama produk kertas. Molekul selulosa saling terkait oleh molekul lain, hemiselulosa terutama terdiri dari xilosa. Kekuatan struktural bahan tanaman dan kertas disebabkan oleh lignin yang memperlihatkan struktur molekul yang sangat kompleks.

Biomassa lignoselulosa terutama terdiri dari selulosa, hemiselulosa, lignin dan ekstrak 
(Kim dkk., 2016). Saat ini, tiga jenis enzim, yaitu, selulase, hemiselulase dan ligninase, digunakan dalam memproses biomassa lignoselulosa (Demuner dkk., 2011).

Ethanol $\left(\mathrm{C}_{2} \mathrm{H}_{5} \mathrm{OH}\right)$ merupakan cairan hasil dari proses fermentasi gula yang berasal dari sumber karbohidrat menggunakan bantuan mikroorganisme. Bioethanol dapat juga diartikan sebagai bahan kimia yang diproduksi dari bahan pangan yang mangandung pati, seperti ubi kayu, ubi jalar, jagung, dan sagu. Bioetanol dapat juga dikatakan sebagai bahan bakar dari minyak nabati yang memiliki sifat menyerupai minyak premium. Kendala dalam proses pembuatan bioetanol yaitu mengacu pada empat besar aspek yaitu bahan baku, teknologi konversi, proses hidrolisis, dan konfigurasi fermentasi (Sarkar dkk., 2011).

Secara umum proses pembuatan bioetanol terdiri dari beberapa tahap, yaitu : tahap persiapan bahan baku (Pre-treatment), hidrolisis, fermentasi dan destilasi.

\section{Pre-treatment}

Pre-treatment merupakan bagian penting dalam proses konversi biomassa menjadi biofuel. Pre-treatment adalah langkah yang digunakan untuk memecah karbohidrat atau polimer pati menjadi monomer seperti glukosa lalu menghasilkan bioethanol Tanadul (2014). Proses pre-treatment bertujuan untuk memecah struktur lignin dan mengganggu struktur kristal selulosa, sehingga cairan asam atau enzim dapat dengan mudah mengakses dan menghidrolisis selulosa (Ellis dkk., 2012).

\section{Hidrolisis}

Dalam proses hidrolisis dapat dilakukan dengan dua cara yaitu hidrolisis asam dan hidrolisis dengan enzim. Hidrolisis asam dapat dilakukan dengan penambahan $\mathrm{H}_{2} \mathrm{SO}_{4}$ atau HCL (Nugroho dkk., 2015). Tujuan dari proses hidrolisis adalah untuk menghasilkan gula monomer yang dapat difermentasi dari hemiselulosa dan kandungan selulosa dari biomassa lignoselulosa. Ini dapat dicapai dengan dua proses yang berbeda, yaitu, hidrolisis asam dan hidrolisis enzimatik (Joshi dkk., 2011).

Menurut Byadgi, dkk., (2015) Dalam proses hidrolisis, selulosa yang ada dalam substrat diubah menjadi etanol menggunakan organisme pendegradasi selulosa setelah proses pra- perawatan. Dalam penelitian yang dilakukan oleh Byadgi, dkk., (2015) bakteri digunakan dalam proses hidrolisis dibandingkan dengan enzim, karena enzim termasuk mahal dan dapat meningkatkan biaya produksi bioetanol. Proses hidrolisis dilakukan pada $\mathrm{pH}$ netral.

\section{Fermentasi}

Dalam proses fermentasi merupakan aktivitas konversi metabolik monosakarida menjadi bioetanol dan produk sampingan lainnya dengan adanya mikroorganisme fermentatif dalam kondisi pendukung yaitu suhu dan kisaran pH (Dalatony, dkk., 2016).

Langkah terakhir dari semua proses ini, etanol diekstraksi dari larutan campuran, kemudian di destilasi untuk disiapkan untuk digunakan sebagai biofuel cair (Miranda, dkk., 2012).

Ada dua jenis utama fermentasi, yaitu: Separate Hydrolysis and Fermentation (SHF) dan Simultaneous Sacchari cation and Fermentation (SSF). Keuntungan utama SHF adalah SHF menyediakan kondisi optimal untuk hidrolisis dan fermentasi (mengingat bahwa proses-proses tersebut terjadi di tangki yang berbeda), membutuhkan bahan kimia yang lebih murah, waktu tinggal yang lebih pendek, dan peralatan yang tidak kompleks (Nguyen, dkk.,2009). SSF membutuhkan kondisi steril yang lebih sedikit dan jumlah enzim yang lebih kecil, dan SSF beroperasi dalam volume reaktor yang lebih kecil dengan waktu pemrosesan yang lebih singkat dan biaya yang lebih sedikit (Balat, dkk., 2008).

\section{Destilasi}

Pada proses destilasi dilakukan dengan menggunakan unit destilasi yang berfungsi untuk memisahkan ethanol dari cairan lain khususnya air. titik didih ethanol pada suhu 
$78^{\circ} \mathrm{C}$ kemudian proses destilasi berlanjut dengan mengalirkan uap zat cair melalui kondensor lalu hasilnya ditampung dalam wadah (Nugroho dkk., 2015).

Tabel 1. Hasil Penelitian

\begin{tabular}{|c|c|c|}
\hline Judul Paper, tahun & Penulis & Hasil Penelitian \\
\hline $\begin{array}{l}\text { Production of } \\
\text { Bioethanol from Waste } \\
\text { Newspaper, } 2016\end{array}$ & $\begin{array}{l}\text { Shuri A. Byadgi, P.B. } \\
\text { Kalburgi }\end{array}$ & $\begin{array}{l}\text { Persentase makasimum bioethanol yang } \\
\text { dihasilkan sebesar } 6,849 \% \mathrm{v} / \mathrm{v} \text { (kultur } \\
\text { murni) dan } 6,031 \% \mathrm{v} / \mathrm{v} \text { (kultur yang } \\
\text { diisolasi) }\end{array}$ \\
\hline
\end{tabular}

\begin{tabular}{|c|c|c|}
\hline $\begin{array}{l}\text { Pembuatan Etanol Dari } \\
\text { Limbah Ampas Kelapa } \\
\text { Dengan Menggunakan } \\
\text { Rhizopus oligosporus } \\
\text { dan Saccharomyces } \\
\text { cereviseae Dengan } \\
\text { Penambahan Phospat, } \\
2012\end{array}$ & $\begin{array}{l}\text { H.Widyatmoko, Sawitri } \\
\text { Anindya Duhita }\end{array}$ & $\begin{array}{l}\text { Hasil kadar etanol pada ampas kelapa tidak } \\
\text { tidak kupas cenderung lebih kecil bila } \\
\text { dibandingkan dengan ampas kelapa kupas. } \\
\text { Tidak kupas sebanyak } 1 \% \text { pada jam } 96 \text { dan } \\
\text { terendah } 0,46 \% \text { pada jam ke } 24 . \\
\text { Sedangkan yang kupas kadar etanol paling } \\
\text { tinggi } 1,14 \% \text { dan yang terendah } 0,46 \% \text {. }\end{array}$ \\
\hline $\begin{array}{l}\text { Bioconversion of Waste } \\
\text { Paper into Bio-Ethanol } \\
\text { by Co-Culture of Fungi } \\
\text { Isolated from } \\
\text { Lignocellulosic Waste, } \\
2016\end{array}$ & $\begin{array}{l}\text { Payal Varotkar, P. M. } \\
\text { Tumane and Durgesh D. } \\
\text { Wasnik }\end{array}$ & $\begin{array}{l}\text { Hasil kadar bioethanol dari Aspergillus sp. } \\
\text { sebesar } 1,3 \mu \mathrm{g} / \mathrm{ml} \text {, kadar bioethanol dari } \\
\text { Trichoderma sp. sebesar } 1,2 \mu \mathrm{g} / \mathrm{ml} \text { dan } \\
\text { hasil kadar ethanol dari mix culture adalah } \\
\text { sebesar } 1,15 \mu \mathrm{g} / \mathrm{ml} \text {. }\end{array}$ \\
\hline
\end{tabular}

\section{PENUTUP}

Limbah Kertas dapat dimanfaatkan untuk produksi bahan bakar melalui aktivitas enzimatis fungi dan ragi. Dalam penelitian sebelumnya persentase maksimum bioethanol yang dihasilkan sebesar 6,849\% v/v (kultur murni) dan 6,031\% v/v (kultur yang di isolasi). Diperlukan penelitian lebih lanjut untuk mengetahui jenis fungi dan ragi terbaik yang dapat membantu pembentukan ethanol.

\section{DAFTAR PUSTAKA}

A. Nugroho et al.,. 2015. Pengolahan Limbah Padat Tapioka Menjadi Etanol Dengan Menggunakan Aspergillus niger, Bacillus licheniformis Dan Saccharomyces cerevisiae. JTL Vol. 7 No. 1 Juni 2015, 17 - 23.

DOI : http://dx.doi.org/10.25105/urbanenvirotech.v7i1

Anwar, Zahid., dkk.,. 2012. Bioethanol productions from rice polish by optimization of dilute acid pretreatment and enzymatic hydrolysis. African Journal of Biotechnology Vol. 11(4), pp. 992-998, 12 January, 2012.

DOI : http://dx.doi.org/10.5897/AJB11.1145

Balat M, Balat H, Öz C. 2008. Progress in bioethanol processing. Progress in Energy and Combustion Science 34, 551-573.

DOI : https://doi.org/10.1016/j.pecs.2007.11.001

Byadgi, A. Shruti dan Kalburgi, P. B. 2015. Production of Bioethanol from Waste Newspaper. International Conference on Solid Waste Management, 5IconSWM 2015. Procedia Environmental Sciences 35 (2016) 555 - 562.

DOI : https://doi.org/10.1016/j.proenv.2016.07.040

Dahlan, Hatta. 2011. Pengolahan Limbah Kertas Menjadi Pulp Sebagai Bahan Pengemas Produk Agroindustri. Prosiding Seminar Nasional AVoER ke-3. 26-27 Oktober 2011. Universitas Sriwijaya: 280-281. 
Demuner, B., Junior, N., Antunes, A., 2011. Technology prospecting on enzymes for the pulp and paper industry. J. Tech. Manage. Innov. 6, 148-158.

DOI : http://dx.doi.org/10.4067/S0718-27242011000300011

El-Dalatony MM, Kurade MB, Abou-Shanab RAI, Kim H, Salama ES, Jeon BH. 2016. Long- term production of bioethanol in repeated-batch fermentation of microalgal biomass using immobilized Saccharomyces cerevisiae. Bioresour Technol 2016;219:98-105.

DOI : $\underline{10.1016 / j . b i o r t e c h .2016 .07 .113}$

H. Widyatmoko et al.,. 2012. Pembuatan Etanol Dari Limbah AMpas Kelapa Dengan

Menggunakan Rhizopus oligosporus dan Saccharomyces cereviseae. JTL Vol 6 No.

1 Desember 2012, 15-22.

DOI : http://dx.doi.org/10.25105/urbanenvirotech.v6i1

Joshi, Bisnu. 2011. Lignocellulosic ethanol production: Current practices and recent developments. Biotechnology and Molecular Biology Review Vol. 6(8), pp. 172182, November 2011. ISSN 1538-2273 C2011 Academic Journals.

Joshua T. Ellis, Neal N. Hengge, Ronald C. Sims, Charles D. Miller.2012. Acetone, butanol, and ethanol production from wastewater algae. Bioresource Technology 111 (2012) 491-495

DOI : https://doi.org/10.1016/j.biortech.2012.02.002

Kim, J.S., Lee, Y.Y., Kim, T.H., 2016. A review on alkaline pretreatment technology for bioconversion of lignocellulosic biomass. Bioresour. Technol. 199, 42-48.

DOI : $\underline{10.1016 / j . b i o r t e c h .2015 .08 .085}$

Kumar, Deepak dan Vijay, Singh. 2018. Bioethanol Production From Corn. Chapter 22. Department of Agricultural and Biological Engineering, University of Illinois at Urbana- Champaign, Urbana, IL, United States.

DOI : $10.1016 /$ B978-0-12-811971-6.00022-X

Kurien, N., Sukumaran, R.K., Pandey. A, 2010. Bioethanol production from rice straw: An overview. Bioresour. Technol. 101, 4767-4774.

DOI : https://doi.org/10.1016/j.biortech.2009.10.079

Ramayanti, Cindi dan Ketty, R. Giasmara. 2017. Bioethanol Production From Waste Paper Using Separate Hydrolysis and Fermentation. Ind. J. Chem. Res, 2017, 5(1), 429-433.

DOI : https://doi.org/10.30598//ijcr.2017.5-cin

Sarkar, N., Ghosh, S. K., Bannerjee, S. \& Aikat, K. (2011). Bioethanol production from agricultural wastes: An overview. Jurnal Renewable Energy, 37, 19-27.

DOI : https://doi.org/10.1016/j.renene.2011.06.045

Tanadul O, VanderGheynst JS, Beckles DM, Powell ALT, Labavitch JM. 2014. The impact of elevated $\mathrm{CO}_{2}$ concentration on the quality of algal starch as a potential biofuel feedstock. Biotechnol Bioeng 2014;111(7):1323-31.

DOI : 10.1002/bit.25203

Varotkar, payal., dkk., 2016. Bioconversion of Waste Paper into Bio-Ethanol by CoCulture of Fungi Isolated from Lignocellulosic Waste. Int. J. Pure App. Biosci. 4 (4): 264-274.

DOI : DOI: http://dx.doi.org/10.18782/23

Zabed, H., Sahu, J., Suely, A., Boyce, A., Faruq, G., 2017. Bioethanol production from renewable sources: current perspectives and technological progress. Renew. Sust. Energ. Rev. 71, 475-501.

DOI : https://doi.org/10.1016/j.rser.2016.12.076 
